\title{
ON THE CALCULATION OF TEXTILE HALLS
}

\author{
DIETER STROEBEL * , JUERGEN HOLL ${ }^{\dagger}$ \\ * technet $\mathrm{GmbH}$ \\ Pestalozzistraße 8, 70563 Stuttgart, Germany \\ e-mail: dieter.stroebel@technet-gmbh.com,web page: http://www.technet-gmbh.com \\ $\dagger$ technet $\mathrm{GmbH}$ \\ Pestalozzistraße 8, 70563 Stuttgart, Germany \\ e-mail: juergen.holl@technet-gmbh.com,web page: http://www.technet-gmbh.com
}

Key words: Textile Halls, Membranes, Hybrid Calculation, Sliding Elements

\begin{abstract}
The calculation of textile membranes should never be carried out independently of the primary construction, because the separation of the calculation into membrane calculation on the one hand and the calculation of the primary structure on the other hand, in which the reaction forces of the retained membrane are applied as external loads, results in quite considerable differences, which actually always lead to a significantly higher steel consumption and are therefore uneconomical. The idea that the savings from the hybrid calculation (i.e. the calculation of the membrane and the primary construction) are only given for double-curved membrane surfaces is to be refuted in this paper. Even with straight membrane surfaces, as they are usually present in textile halls in general, we obtain smaller cross-sections for the primary construction through the coupled or hybrid calculation. Nevertheless, to date these more accurate models are little used in practice, because their generation is time-consuming and not all requirements can be represented in usual software packages. In particular, membrane fields that are not firmly attached to the steel or aluminum elements, but rather membrane surfaces that slide over them, are a problem. In the article it is shown that a fast modelling under consideration of sliding conditions yields results that are below the usual deformations and metal quantities.
\end{abstract}

\section{REFERENCES}

\section{REFERENCES}

[1] Linkwitz, K. and Schek, H.-J., (1971), `Einige Bemerkungen zur Berechnung von vorgespannten Seilnetzkonstruktionen', Ingenieur-Archiv 40, 145-158.

[2] Schek, H.-J., (1974), 'The force density method for form finding and computation of general networks', Computer Methods in Applied Mechanics and Engineering 3, 115-134.

[3] Gründig, L., (1975), ’Die Berechnung von vorgespannten Seilnetzen und Hängenetzen unter Berücksichtigung ihrer topologischen und physikalischen Eigenschaften und der Ausgleichungsrechnung', Dissertationsschrift, DGK Reihe C, Nr. 216, 1976 and SFB 64-Mitteilungen 34/1976.

[4] Singer, P.,(1995), `Die Berechnung von Minimalflächen, Seifenblasen, Membrane und Pneus aus geodätischer Sicht', Dissertationsschrift, DGK Reihe C, Nr. 448, 1995.

[5] Ströbel, D., (1997), 'Die Anwendung der Ausgleichungsrechnung auf elastomechanische Systeme', DGK, Reihe C, Nr. 478.

[6] Ströbel, D. und Wagner, R,: Flexibilitätsellipsoide zur Beurteilung von Tragwerken. In Journal: Bauingenieur, Vol. 78, pp. 509-516, 2003.

[7] Easy Training Manual, technet GmbH, Stuttgart 2021 